\title{
UPAYA OPTIMASI KINERJA MELALUI BASIC DESIGN REVITALISASI PADA INST ALASI PENGOLAHAN AIR LIMBAH (IPAL) CISIRUNG, BANDUNG SELATAN
}

\section{THE EFFORT OF PERFORMANCE OPTIMIZATION WITH BASIC DESIGN OF REVITALIZATION FOR TREATMENT INSTALATION OF WASTE WATER CISIRUNG, SOUTH BANDUNG}

\author{
Ratna Adiana1), Ratna Hidayat1), Iskandar A. Yusuf(1),Misbahudin'2), Ahmad Taufiq1) \\ ${ }^{1)}$ Puslitbang Sumber Daya Air, Kementerian Pekerjaan Umum dan Perumahan Rakyat \\ Jl. Ir. H. Djuanda No. 193, Bandung, 40135 \\ 2) Institut Teknologi Bandung \\ Email: ratna.adiana@yahoo.com
}

Diterima: Desember 2017 ;Direvisi: Januari; Disetujui: Februari 2018

\begin{abstract}
ABSTRAK
Berkaitan dengan upaya restorasi dan Pengendalian Pencemaran Air (PPA) yang masuk ke Sungai Citarum bagian hulu, kegiatan revitalisasi IPAL Cisirung dilakukan untuk meningkatkan kapasitas IPAL Cisirung agar kinerjanya menjadi lebih optimal. IPAL Cisirung dibangun dengan teknologi pengolahan air limbah secara fisika, kimia dan biologi. Kegiatan ini dilakukan dengan melakukan survei lapangan dan pengujian sampel di laboratorium. Debit air limbah saat ini yang masuk ke IPAL Cisirung sebesar 206,10 L/detik. Tujuan dari kegiatan ini adalah untuk membuat basic design revitalisasi IPAL Cisirung sebagai acuan Detail Engineering Design (DED) dengan kapasitas perencanaan sebesar 350 L/detik. Pengambilan sampel air dilakukan berdasarkan gambaran unit pengolahan yang harus direvitalisasi, yakni bak ekualisasi, outlet bak pengendap I, dan bak pengendap II. Hasil uji penelitian di laboratorium secara kimiawi menunjukan kondisi optimum kekeruhan adalah 28,6 NTU. Revitalisasi unit pengolahan biologi dirancang menggunakan teknologi Moving Bed Biofilm Reactor (MBBR). Keuntungan teknologi MBBR adalah sangat efektif dalam mereduksi COD sebesar 85\%, mereduksi nitrogen melalui proses nitrifikasi dan mampu menyerap TSS atau MLSS sebanyak $2400 \mathrm{mg} / \mathrm{L}$.
\end{abstract}

Kata Kunci : Basic Design, Cisirung, IPAL, MBBR, Revitalisasi

\begin{abstract}
In relation to the efforts of restoration and water pollution control (PPA) into the upstream Citarum River, the revitalization of IPAL Cisirung is done to increase the capacity to optimize its performance. IPAL Cisirung is built with wastewater, chemical and biological waste treatment technology. This activity is carried out by conducting field survey and sample testing in the laboratory. The current wastewater discharge that goes to IPAL Cisirung is 206,10 L/sec. The purpose of this activity is to make basic design of IPAL Cisirung revitalization as reference of Detail Engineering Design (DED) with planning capacity of $350 \mathrm{~L} / \mathrm{sec}$. Water sampling is done based on the description of the processing unit that must be revitalized, namely equalization tub, sedimentation bed outlet I and sedimentation basin II. The result of laboratory test showed that the optimum condition of turbidity was 28.6 NTU. Revitalization of the biological treatment unit is designed using the Moving Bed Biofilm Reactor (MBBR) technology. The advantages are very effective in reducing COD by 85\%, reducing nitrogen through nitrification process and able to absorb TSS or MLSS as much as 2400 $\mathrm{mg} / \mathrm{L}$.
\end{abstract}

Keyword : Basic Design, Cisirung, IPAL, MBBR, Revitalization 


\section{PENDAHULUAN}

Pemerintah Indonesia telah membuat beberapa aturan Undang-undang (UU) terkait upaya Pengendalian Pencemaran Air (PPA). UU terkait saat ini adalah UU No. 32 Tahun 2009 tentang Perlindungan dan Pengelolaan Lingkungan Hidup yang kemudian diturunkan ke dalam berbagai jenis aturan terkait.

Salah satu sungai besar dan panjang yang ada di Indonesia adalah Sungai Citarum yang terletak di Provinsi Jawa Barat. Sungai ini dimanfaatkan sebagai sumber air baku untuk beberapa kabupaten/kota, termasuk ibukota Jakarta. Ketergantungan yang tinggi terhadap keberadaan Sungai Citarum juga dapat dilihat dari pembangunan tiga waduk kaskade raksasa yaitu Saguling, Cirata, dan Jatiluhur. Waduk-waduk tersebut dapat menghasilkan listrik dengan kapasitas mencapai 1.900 MW dan digunakan untuk memenuhi kebutuhan listrik nasional dan irigasi lahan sawah seluas lebih dari $240.000 \mathrm{Ha}$ (Puslitbang Sumber Daya Air, 2012). Kualitas air di Sungai Citarum telah menjadi permasalahan yang serius karena parameter kualitas airnya sudah dikategorikan tercemar cukup berat.

Dalam rangka peningkatan kualitas air di hulu Sungai Citarum pada ruas Cisirung, Dayeuh Kolot,
Bandung, Jawa Barat dilakukan upaya pengendalian pencemaran limbah industri dengan dibangunnya Instalasi Pengolahan Air Limbah (IPAL) Cisirung. Pembangunan IPAL terkait dengan industri-industri yang beroperasi di sepanjang jalan Mohammad Toha, Bandung. Pada rentang waktu 1997 - 2000, terdapat 52 industri yang berproduksi, kemudian mengalami penurunan di tahun 2001 - 2008 menjadi 25 industri, dan terkini pada tahun 2016, tercatat sebanyak 24 industri saja yang berproduksi (PT. Darma Indra, 2008). Pada tahun 2016, 24 industri yang berproduksi memiliki total debit air limbah sebesar 206,61 L/detik.

IPAL Cisirung dibangun dengan teknologi proses pengolahan air limbah secara fisika - kimia - biologi dengan debit pengolahan air limbah ratarata sebesar $175 \mathrm{~L} / \mathrm{s}$, dengan diagram alir prosesnya seperti ditunjukkan pada Gambar 1 (Yusuf dkk., 2016). IPAL Cisirung dibangun dengan konsep pengolahan fisika kimia yang direncanakan dan dibangun oleh Puslitbang Sumber Daya Air. Pada tahun-tahun berikutnya, IPAL Cisirung mengalami beberapa kali redesign dan pengembangan hingga saat ini merupakan suatu IPAL terpadu.

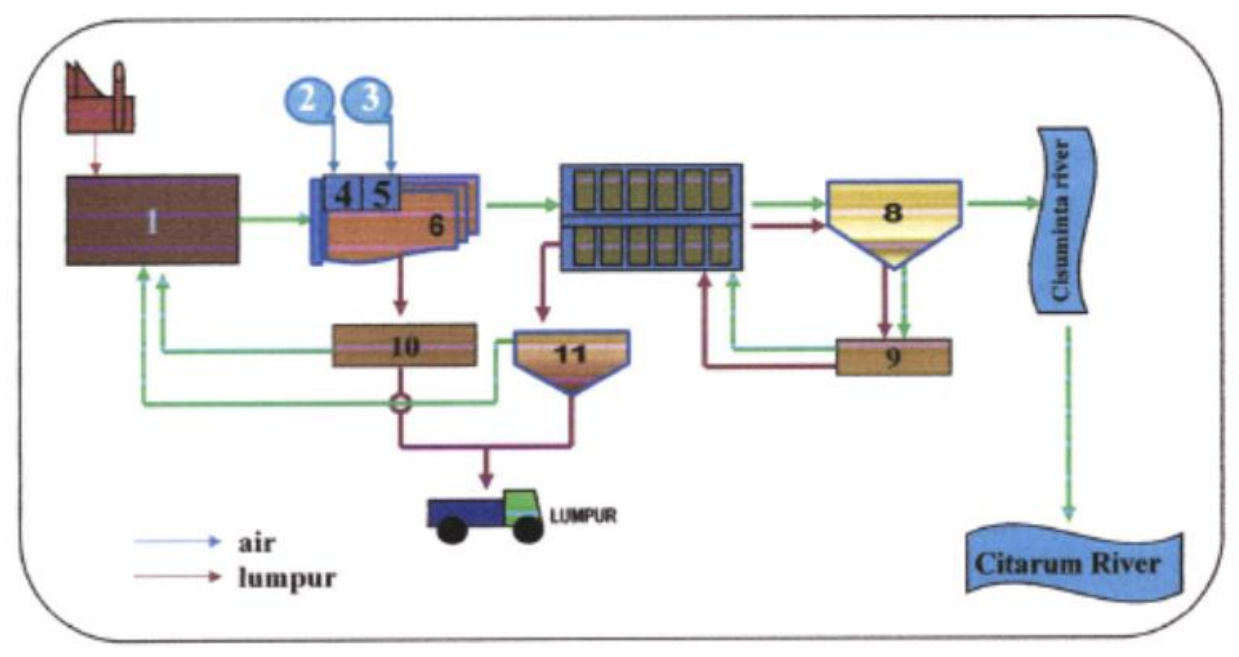

Gambar 1 Diagram Alir Proses Ipal Cisirung

Keterangan:
1. Bak ekualisasi
2. Penampung Koagulan
3. Penampung Flokulan
4. Bak Koagulasi

5. Bak Flokulasi

6. Bak Sedimentasi

7. Bak Kontak Stabilisasi

8. Bak Sedimentasi 2
9. Resirkulasi

10. Pengering Lumpur

11. Thickener 
IPAL terpadu ini memiliki unit-unit pengolahan yang terdiri atas pengolahan pretreatment berupa kolam equalization basin, unit pengolahan kimia berupa unit pengadukan cepat, pengadukan lambat dilengkapi dengan unit pembubuhan bahan kimia (koagulan) dan sedimentasi, unit pengolahan biologi (activated sludge), unit pengolahan lumpur, serta bangunanbangunan pendukung termasuk laboratorium dan gedung kantor. Disamping unit IPAL, lokasi IPAL ini juga dilengkapi dengan sistem pengendalian banjir berupa pintu air dan pompa pengendali banjir. Pada saat ini IPAL dioperasikan oleh pihak swasta yang bekerjasama dengan Pemda Kabupaten Bandung dan Puslitbang Sumber Daya Air.

Kinerja IPAL Cisirung terhitung kurang optimal. Hal ini dapat dilihat dari tidak berfungsinya beberapa unit pengolahan secara baik. Unit pengolahan kimia tidak berjalan dengan baik sehingga membuat penyisihan warna limbah tekstil tidak optimal, unit pengolahan biologi juga tidak berfungsi dengan baik sehingga kemungkinan kandungan bahan organik masih tinggi, unit pengolahan lumpur tidak difungsikan sehingga lumpur kemungkinan tidak terkuras dari unit-unit sedimentasi, dan unit pengendali banjir yang juga tidak berfungsi sehingga menyebabkan air limbah tidak dapat dialirkan ke Sungai Citarum, serta membuat lokasi IPAL terendam air banjir.

Melihat kondisi kinerja IPAL Cisirung di atas, diperlukan perbaikan untuk mencapai kondisi optimal instalasi melalui kegiatan revitalisasi IPAL Cisirung. Tujuan dari kegiatan ini adalah didapatkannya basic design revitalisasi IPAL Cisirung sebagai acuan Detailed Engineering Design (DED) Revitalisasi IPAL Cisirung.

\section{Lokasi Kegiatan}

Lokasi IPAL Cisirung berada di Jalan Cisirung, yang merupakan bagian dari Jalan Mohamad Toha. Jalan tersebut bermula dari jembatan tol Cipularang segmen Mohamad Toha hingga Jalan Cisirung dan berdekatan dengan Sungai Citarum. Lokasi IPAL Cisirung terletak secara strategis untuk mengakomodasi buangan air limbah dari industri-industri Bandung Selatan yang berada di Sungai Citarum bagian hulu. Lokasi kegiatan dan sistem penyaluran air limbah industri dapat dilihat pada Gambar 2.

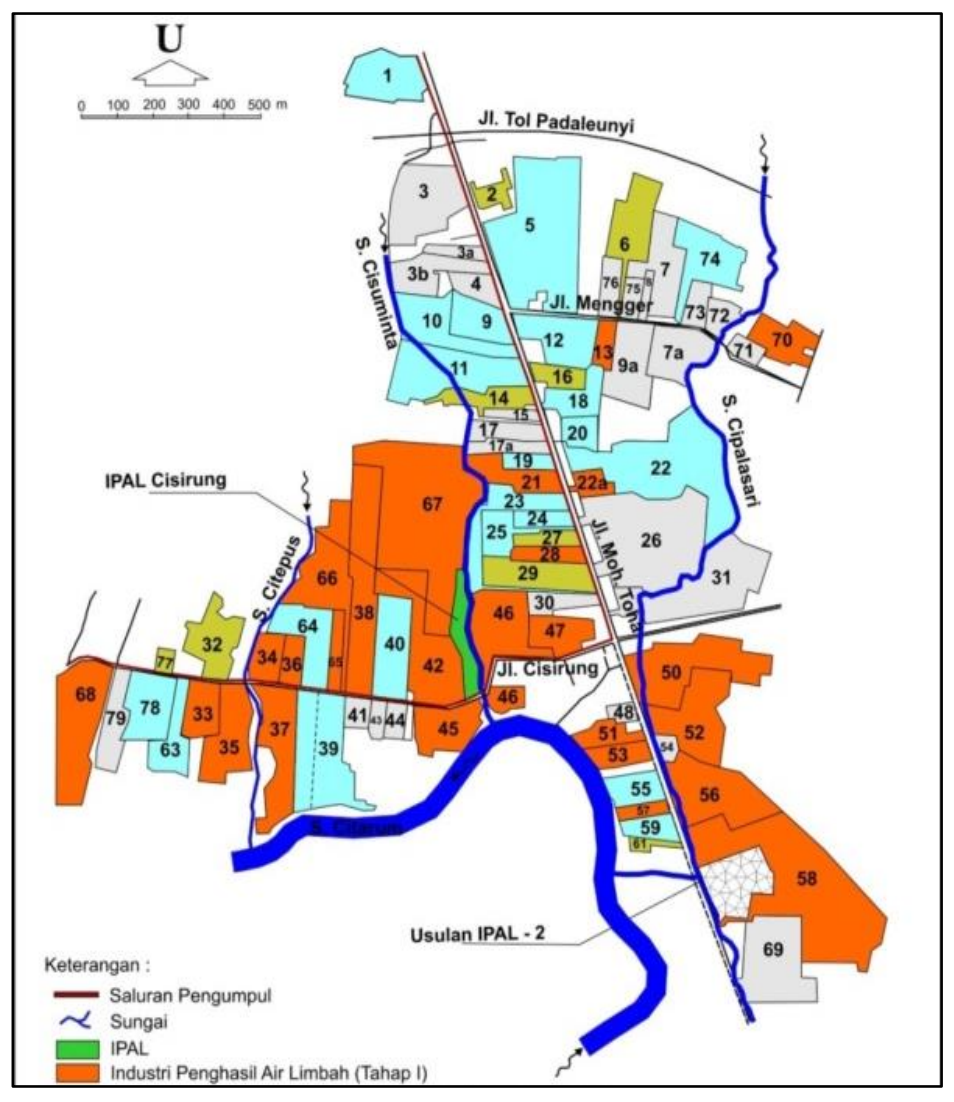

Gambar 1 Sistem penyaluran air limbah industri Bandung Selatan (Puslitbang Sumber Daya Air, 2016). 


\section{KAJIAN PUSTAKA}

\section{Teknologi Pengolahan Air Limbah IPAL Cisirung}

Pengolahan air limbah di IPAL Cisirung menggunakan dua proses pengolahan utama, yaitu lumpur aktif (activated sludge) dan kolam stabilisasi (Puslitbang Sumber Daya Air, 2016). Pengolahan air limbah dengan proses lumpur aktif konvensional secara umum terdiri dari bak pengendap awal, bak aerasi dan bak pengendap akhir, serta bak klorinasi untuk membunuh bakteri patogen. Secara umum pengolahannya adalah untuk mengalirkan air limbah kedalam bak yang di aliri udara (bak aerasi). Selanjutnya dalam bak tersebut akan tumbuh koloni bakteri berwarna kelabu hingga coklat-kehitaman. Koloni bakteri inilah yang disebut sebagai lumpur aktif. Koloni bakteri akan terus tumbuh membesar sehingga membentuk gumpalan (flok). Gumpalangumpalan ini kemudian di endapkan di bak pengendap II, dengan cara mengalirkan air limbah dari bak aerasi. Endapan lumpur yang terbentuk di bagian bawah bak pengendap sebagian dibuang dan sebagian yang lain dikembalikan ke bak aerasi, dan cairan yang ada dibagian atas bak pengendap akan tampak jernih. Cairan yang jernih ini adalah air limbah yang sudah bersih dari bahan organik pencemar. Skema proses pengolahan air limbah dengan sistem lumpur aktif dapat dilihat pada Gambar 3.

Dalam proses pengolahan air limbah di kolam stabilisasi, limbah dan lumpur bercampur dalam tangki reaktor kecil untuk waktu yang singkat (antara 20 - 40 menit), aliran campuran tersebut dialirkan ke tangki penjernih dan lumpur dikembalikan ke tangki stabilisasi dengan waktu tinggal 4 - 8 jam. Sistem ini menghasilkan sedikit lumpur, terdiri dari 3 unit kolam, yaitu kolam anaerobik, kolam fakultatif, dan kolam maturasi. Perbedaan ketiga kolam terdapat pada kedalamannya. Kolam anaerobik memiliki kedalaman 2,5 - $4 \mathrm{~m}$, kolam fakultatif 1,5 - $2 \mathrm{~m}$, dan kolam maturasi $1 \mathrm{~m}$. Skema proses pengolahan limbah dengan kolam stabilisasi digambarkan dalam Gambar 4.

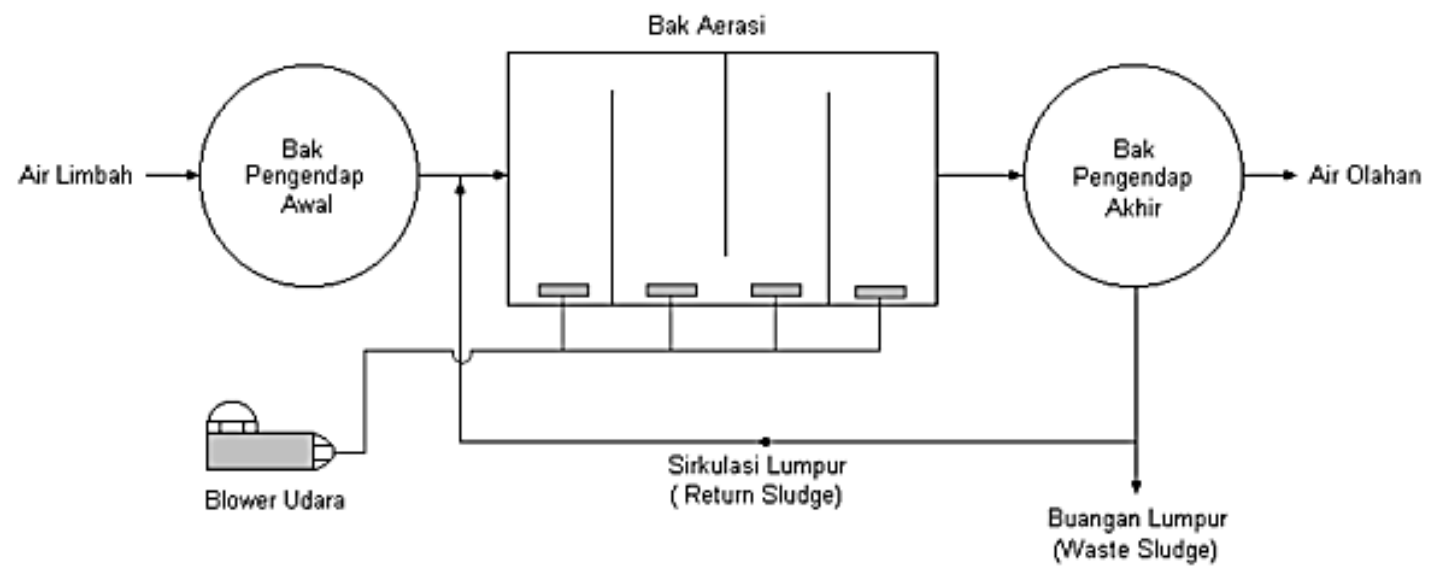

Gambar 3 Diagram proses pengolahan air limbah dengan proses lumpur aktif standar (konvensional).

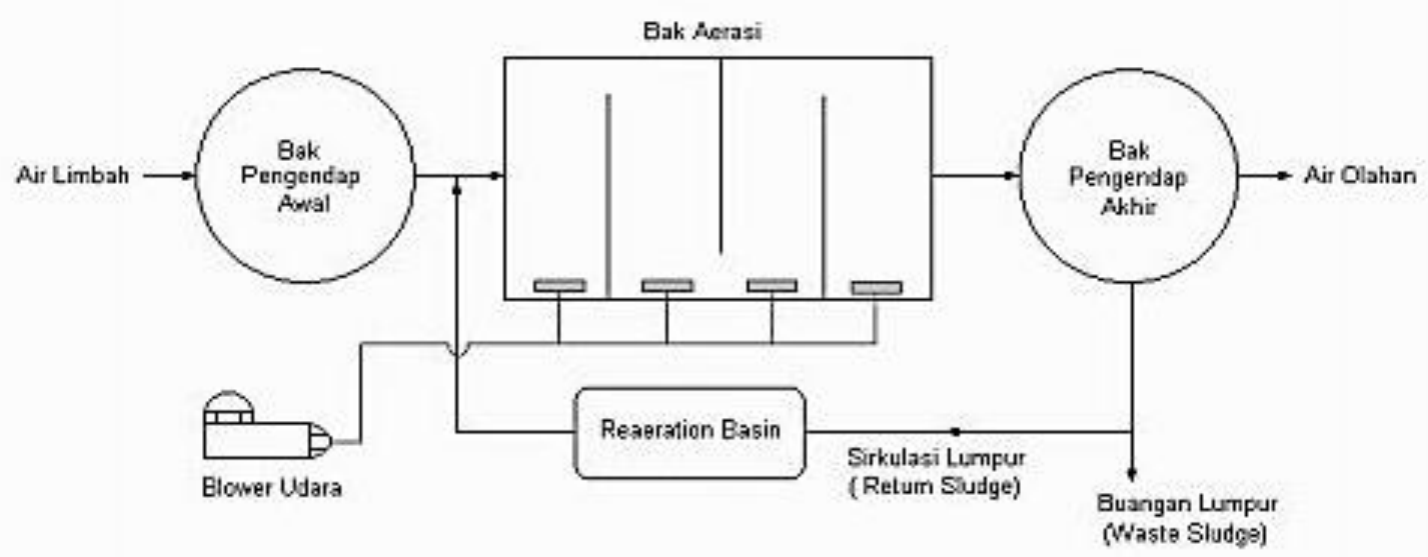

Gambar 4 Diagram proses pengolahan air limbah dengan kolam stabilisasi 


\section{Teknologi Revitalisasi IPAL}

Dalam revitalisasi IPAL dikenal beberapa teknologi, seperti Rotating Bilological Contractor (RBC), Membrane Bioreactor (MBR), dan Moving Bed Biofilm Reactor (MBBR) (Tchobanoglous dkk., 2003). Teknologi RBC adalah salah satu teknologi pengolahan air limbah yang mengandung polutan organik yang tinggi secara biologis dengan sistem biakan melekat (attached culture). Prinsip kerja pengolahan air limbah dengan RBC yakni air limbah yang mengandung polutan organik dikontakkan dengan lapisan mikro-organisme (microbial film) yang melekat pada permukaan media di dalam suatu reaktor. Media tempat melekatnya film biologis ini berupa piringan (disk) dari bahan polimer atau plastik yang ringan dan disusun dari berjajar-jajar pada suatu poros sehingga membentuk suatu modul atau paket, selanjutnya modul tersebut diputar pelan dalam keadaan tercelup sebagian ke dalam air limbah yang mengalir secara kontinyu ke dalam reaktor tersebut.

Mekanisme proses metabolisme di dalam sistem biofilm secara aerobik menunjukan suatu sistem biofilm yang terdiri dari medium penyangga, lapisan biofilm yang melekat pada medium, lapisan air limbah dan lapisan udara yang terletak di luar. Senyawa polutan yaang ada di dalam air limbah misalnya senyawa organik (BOD, COD), ammonia, fosfor dan senyawa lainnya akan terdifusi ke dalam lapisan atau film biologis yang melekat pada permukaan medium. Skema teknologi RBC diperlihatkan pada Gambar 5.

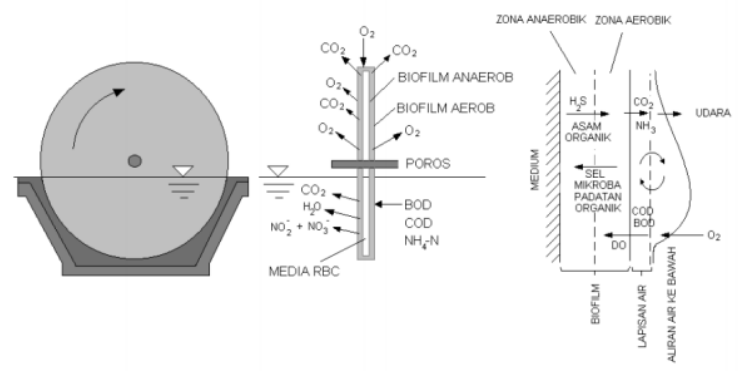

Gambar 5 Teknologi RBC.

Teknologi MBR merupakan suatu sistem pengolahan air limbah yang mengaplikasikan penggunaan membran yang terendam di dalam bioreaktor. Proses yang terjadi di dalam bioreaktor mirip dengan lumpur aktif konvensional. Zat organik di dalam air limbah akan didegradasi secara biologis oleh mikroorganisme aerob kemudian terjadi pemisahan lumpur. Teknologi MBR tidak memerlukan bak pengendapan (clarifier) sehingga dapat menghemat penggunaan lahan, konsentrasi MLSS (mixed liquor suspended solids) yang tinggi memaksimalkan jumlah BOD yang masuk ke dalam modul MBR untuk diolah sehingga dapat mengurangi waktu pengolahan, pembuangan lumpur dapat dilakukan langsung dari dalam reaktor, dan kualitas efluen hasil pengolahan yang tinggi, sehingga hasil olahannya dapat digunakan kembali (misal untuk boiler). Teknologi ini digambarkan melalui skema pada Gambar 6.

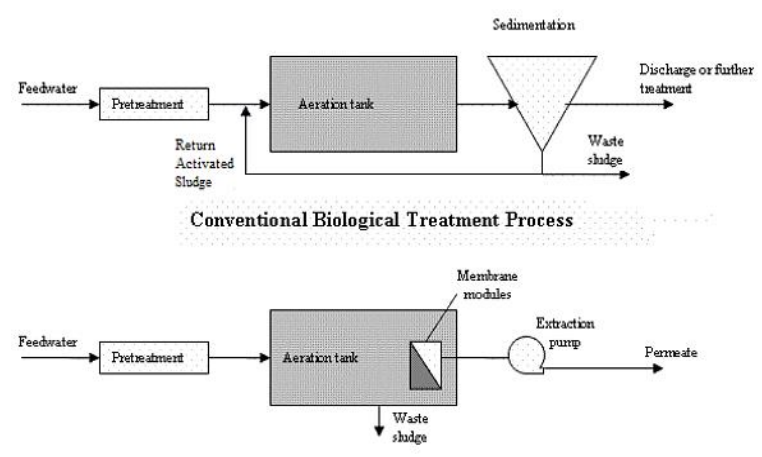

Membrane Bioreactor (MBR) Process

\section{Gambar 6 Teknologi MBR}

Teknologi MBBR menggunakan beribu biofilm dari polythylene yang tercampur di dalam suatu reaktor dengan aerasi terus menerus. Luas permukaan media plastik yang digunakan besar berkaitan dengan pertumbuhan bakteri. Biomassa tumbuh di permukaan sebagai film tipis yang ketebalannya bervariasi antara 50 - 300 mikro m. Medium atau kasar diffusers gelembung seragam ditempatkan di bagian bawah reaktor mempertahankan oksigen terlarut (DO) konsentrasi $>2,5-3 \mathrm{mg} / \mathrm{L}$ untuk menghilangkan BOD. Teknologi ini mampu memproses secara alamiah perawatan bakterinya sendiri pada level optimum dari biofilm yang produktif. Dalam prosesnya, tidak membutuhkan pengembalian lumpur dan tidak perlu mengatur $\mathrm{F} / \mathrm{M}$ ratio atau tingkat MLSS yang ada dalam reaktor. MBBR sangat efektif dalam mereduksi BOD, nitrifikasi, dan menghilangkan nitrogen. Skema teknologi MBBR dapat dilihat pada Gambar 7.

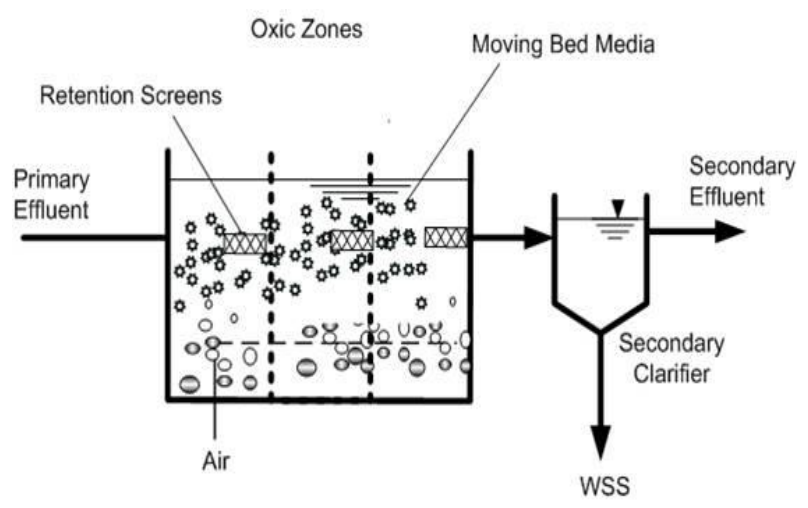

Gambar 7 Teknologi MBBR 
Teknologi MBBR memiliki keuntungan di antaranya kapasitas perawatan yang sama seperti sistem lumpur aktif, sejalan dengan oksidasi karbon dan nitrogen, retensi biomassa bersifat clarifier-independent, proses aliran berkelanjutan yang tidak memerlukan siklus operasional khusus untuk kontrol ketebalan biofilm, dan pemisahan cairan-padatan dapat dicapai dengan berbagai proses, termasuk proses konvensional dan kompaksi yang tinggi (Mcquarrie dan Boltz, 2011). Proses biologi dalam teknologi MBBR adalah salah satu proses pengolahan biologis untuk pengolahan air limbah yang memberikan desain pabrik perawatan yang kompak untuk mengatasi kekurangan dalam proses lumpur aktif dan menghasilkan efluen berkualitas lebih tinggi (Lariyah dkk., 2016).

Dalam melakukan revitalisasi IPAL nantinya perlu dibuat basic design. Basic design adalah laporan dan proposal awal yang menjelaskan operasi dan rencana yang direncanakan (College of Tropical Agriculture and Human Resources, 2010).

\section{Perkembangan Debit Pengolahan Air Limbah}

Debit air limbah yang dibuang ke IPAL Cisirung bervariasi. Selain karena kapasitas produksi industri tersebut juga berbeda, hal ini juga disebabkan karena beberapa industri di wilayah Dayeuhkolot juga sudah memiliki IPAL sendiri sehingga hanya sebagian kecil limbahnya yang dibuang ke IPAL Cisirung. Dari data yang didapat, debit operasional atau kapasitas pengolahan air limbah yang diolah berkisar 206,61 L/detik atau hanya sekitar 50\% dari kapasitas IPAL Cisirung terpasang. Fluktuasi debit pengolahan air limbah yang terjadi saat ini di IPAL Cisirung selain disebabkan oleh jumlah industri yang berfluktuasi dan jam operasional pabrik yang cenderung berubah-ubah menyesuaikan dengan kondisi ekonomi saat ini. Karakteristik limbah cair dari masing-masing industri yang masuk ke IPAL ditentukan berdasarkan nilai rata-rata yang proposional terhadap debit (PT. Darma Indra, 2008).

Dalam perancangan sistem instalasi pengolahan air limbah dilakukan analisa terhadap beberapa alternatif unit pengolahan yang bervariasi untuk mendapatkan kombinasi yang optimal. Kelayakan sistem pengolahan air limbah terpadu ditinjau dari berbagai hal, yaitu biaya investasi/konstruksi pembangunan IPAL, biaya operasional IPAL, aspek ekonomi, keuntungan yang diperoleh IPAL terpadu, proses pengolahan, pengoperasian dan pemeliharaan IPAL, serta dampak terhadap lingkungan.

\section{METODOLOGI}

Metodologi dalam kegiatan penelitian ini mencakup pekerjaan persiapan, survei dan pengujian untuk mengidentifikasi kondisi fisik dan kinerja unit-unit pengolahan IPAL Cisirung, dan pekerjaan analisa. Pekerjaan persiapan yang dilakukan adalah pengumpulan data sekunder yang dilakukan melalui studi literatur, kunjungan ke lembaga terkait, dan diskusi dengan pengelola IPAL Cisirung.

Survei dan pengukuran dilakukan di lapangan. Sampel yang diperoleh kemudian dibawa ke laboratorium. Metode perhitungan dan pengujian kualitas air limbah menggunakan standar dari American Public Health Association (1999) dan Standar Nasional Indonesia (SNI) bidang Pekerjaan Umum tentang air dan air limbah di antaranya SNI 6989.59.2008, SNI 6989.2:2009, dan SNI 6989.72:2009. Sementara itu, metode yang digunakan dalam pembuatan basic design revitalisasi IPAL Cisirung adalah dengan metode observasi lapangan, studi banding, dan desk study.

\section{HASIL DAN PEMBAHASAN}

Sistem yang diterapkan di IPAL Cisirung adalah dengan proses fisika, kimia dan biologi. Pada proses kimia menggunakan bahan koagulan polimer dan proses biologi untuk penumbuhan bakteri maka dilakukan penambahan nutrien (sampai dengan Juni 2015). Akan tetapi, sejak bulan Juli 2014 sampai dengan bulan Juli 2015 proses IPAL diubah menggunakan full biology treatment, karena tidak berhasil sesuai harapan, selanjutnya proses IPAL dikembalikan lagi seperti semula sejak bulan September 2016 sampai saat ini.

Pengambilan sampel dilakukan berdasarkan gambaran unit pengolahan yang direvitalisasi, yakni bak ekualisasi, outlet bak pengendap I, dan bak pengendap II. Unit-unit tersebut dikategorikan cukup parah dikarenakan hampir semua parameter yang diuji melebihi standar mutu limbah cair dan kendala seperti banjir menyebabkan IPAL berhenti beroperasi untuk sementara waktu akibat kerusakan peralatan mekanikal-elektrikal dan penurunan pendapatan IPAL yang menyebabkan kerugian secara teknik dan finansial.

Pengkajian kualitas air hasil pengolahan IPAL Cisirung dilakukan melalui pengambilan dan pemeriksaan kualitas air secara grab (sesaat) di beberapa tempat, yaitu IPAL Cisirung pada bak ekualisasi, setelah proses kimia (bak pengendap pertama) dan setelah proses biologi (bak pengendap ke dua) dan badan penerima di Sungai Citarum dilakukan sebelum dan sesudah IPAL 
Cisirung. Parameter yang diperiksa di lapangan adalah $\mathrm{pH}$, daya hantar listrik, temperature, dan oksigen terlarut sedangkan parameter lainnya dianalisis di laboratorium.

Parameter-parameter kualitas air IPAL Cisirung yang diuji di laboratorium terdiri dari BOD-5, COD, Total Suspended Solid, Stirred Sludge, Fenol Total, Krom Total, Amonia Total, Sulfida, Minyak dan Lemak, serta $\mathrm{pH}$. Parameter kualitas air yang digunakan mengikuti aturan baku mutu air limbah domestik dan industri sesuai Peraturan Menteri Lingkungan Hidup Republik Indonesia (PERMENLHRI) Nomor 5 Tahun 2014 dan Nomor P.68 Tahun 2016. Titik pengambilan sampel dilakukan pada bak ekualisasi, outlet bak pengendap I, dan bak pengendap II. Berdasarkan hasil pengujian, kualitas air di ketiga titik pengambilan sampel dikategorikan cukup parah. Hal ini berkaitan dengan sebagian besar parameter yang diuji melebihi batas baku mutu air yang didasarkan pada PERMENLHRI No. 5 Tahun 2014. Parameterparameter fenol total, krom total, minyak dan lemak masih berada di bawah ambang batas mutu air limbah industri.

Revitalisasi IPAL Cisirung dilakukan dengan menggunakan teknologi biofilter dan Moving Bed Bioflm Reactor (MBBR). Pemilihan teknologi ini sudah dianalisis kelebihan dan manfaatnya dibandingkan dengan teknologi lain. Gambar 8 berikut ini merupakan usulan teknologi MBBR yang akan digunakan untuk merevitalisasi pengolahan IPAL Cisirung.

\section{Berikut penjelasan detail terkait basic design revitalisasi IPAL Cisirung.}

\section{Bak Ekualisasi dan Bak Pengendap 1}

Elevasi dasar bak berada pada posisi -2,50 m berupa dasar bak tanah. Dasar bak ini diperdalam menjadi $-4,00 \mathrm{~m}$ berupa pelat lantai beton tebal $\mathrm{t}=200 \mathrm{~mm}$. Elevasi sisi atas bak adalah $+3,50 \mathrm{~m}$. Bak ekualisasi dan bak pengendap dibagi menjadi 3 bagian yang dibatasi oleh tambahan tembok pemisah. Selain itu, direncanakan lubang berukuran $1 \times 1 \mathrm{~m}^{2}$ ditengah tembok pemisah tambahan.

Struktur pelat lantai beton bertulang sistem half slab merupakan struktur pelat dengan pekerjaan konstruksi pemasangan pelat lantai beton bertulang separuh precast dan separuhnya lagi in situ. Elemen separuh precast menyesuaikan dengan beban maksimal yang masih aman diangkat dengan tower crane. Denah Bak Ekualisasi dan Bak Pengendap I ditujukan pada Gambar 9.

\section{Bak Aerasi}

Tambahan luas bak aerasi pada lahan yang terbatas direncanakan di atas bangunan bak aerasi existing, dengan demikian revitalisasi bak aerasi berupa bangunan satu lantai (Gambar 10). Pondasi tiang pancang 5D400 mM - 30 M (interval $8 \mathrm{mM}$ ) dipasang pada kolom K. Per pondasi ukuran $600 * 2400 \mathrm{mM}^{2}$, yang diperlihatkan pada Gambar 11.

\section{Treatability Trial Pertama: on-going}

MLSS : $2400 \mathrm{mg} / \mathrm{l}$

COD HO : 565,6 mg/l

COD H+1 $: 178 \mathrm{mg} / \mathrm{l}$

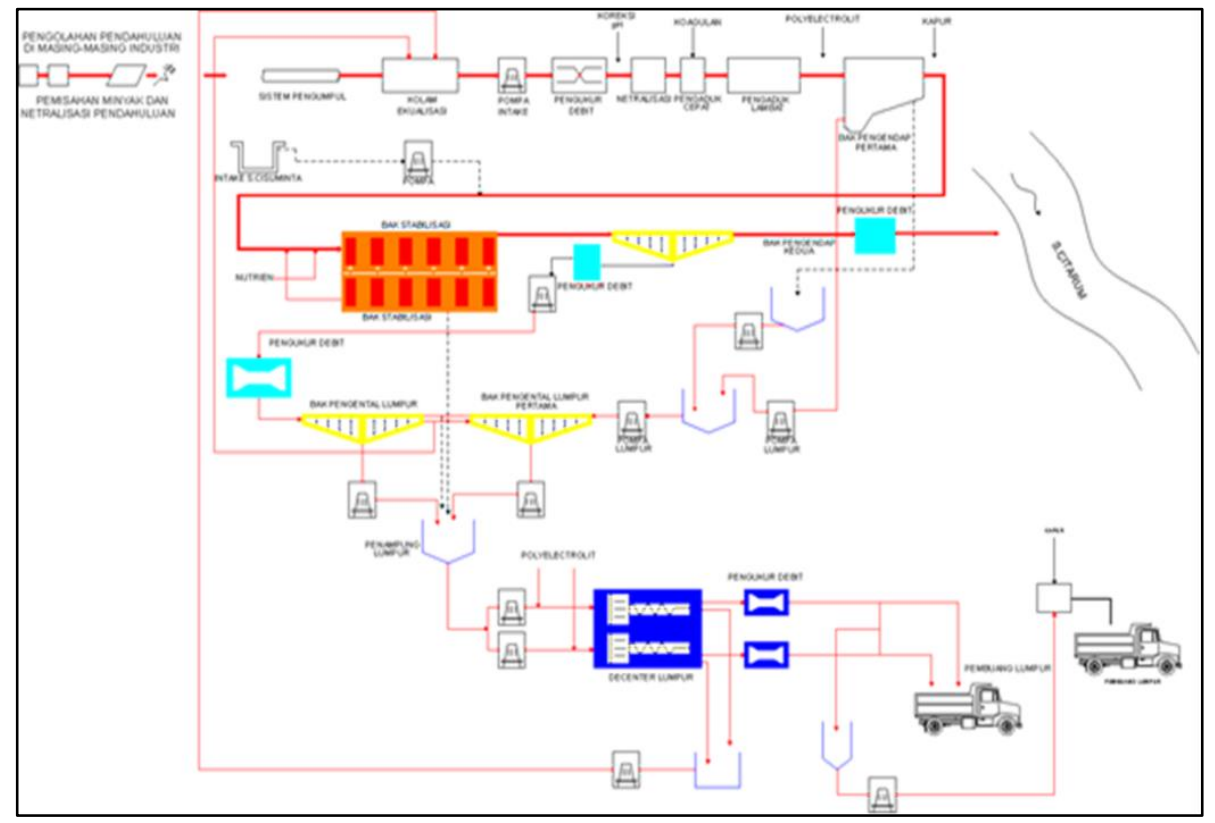

Gambar 8 Usulan perbaikan unit-unit di IPAL Cisirung 
Jurnal Sumber Daya Air Vol.14 No. 1 Mei 2018: 47-60
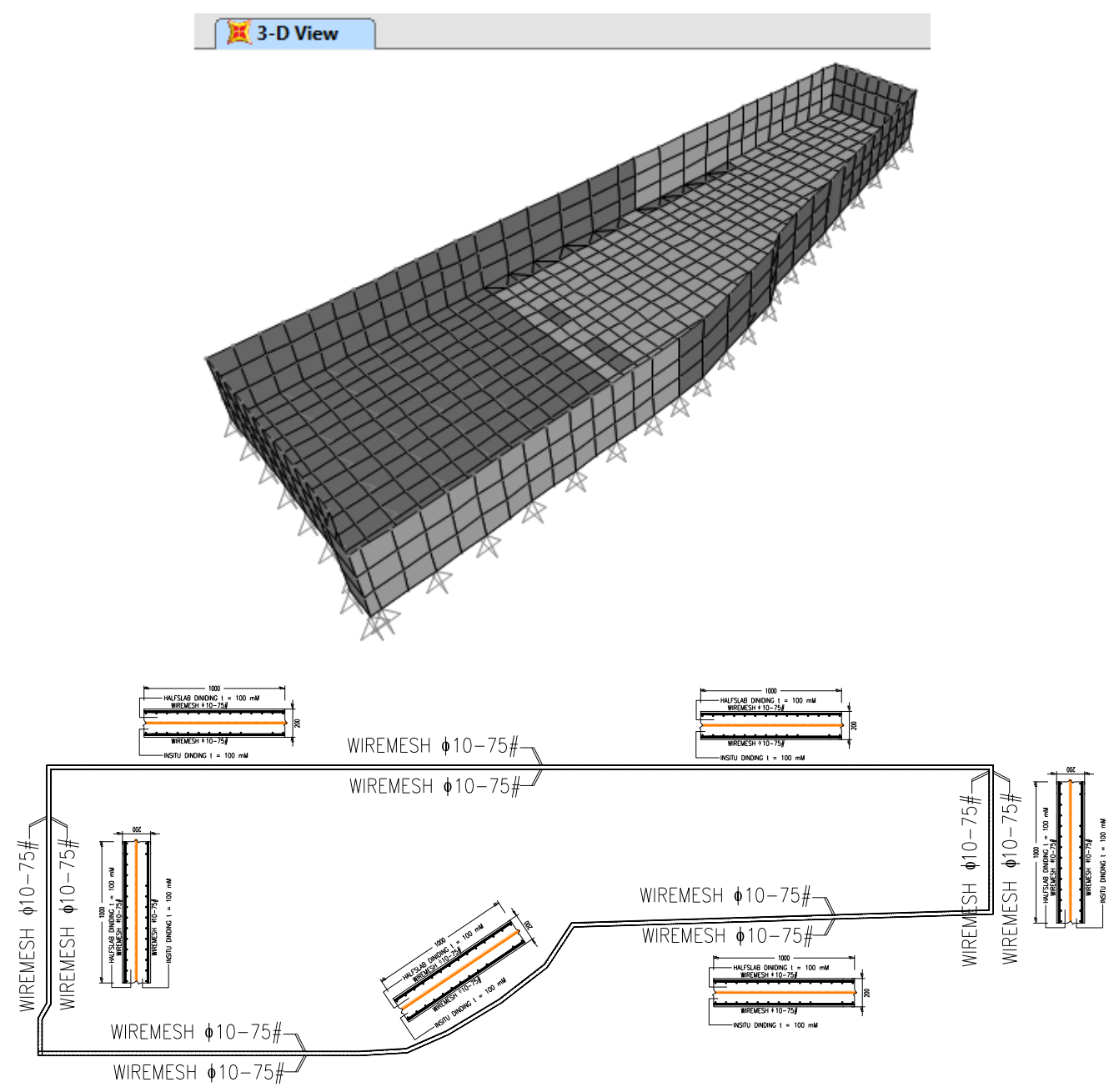

Gambar 9 Denah Bak Ekualisasi dan Bak Pengendap I
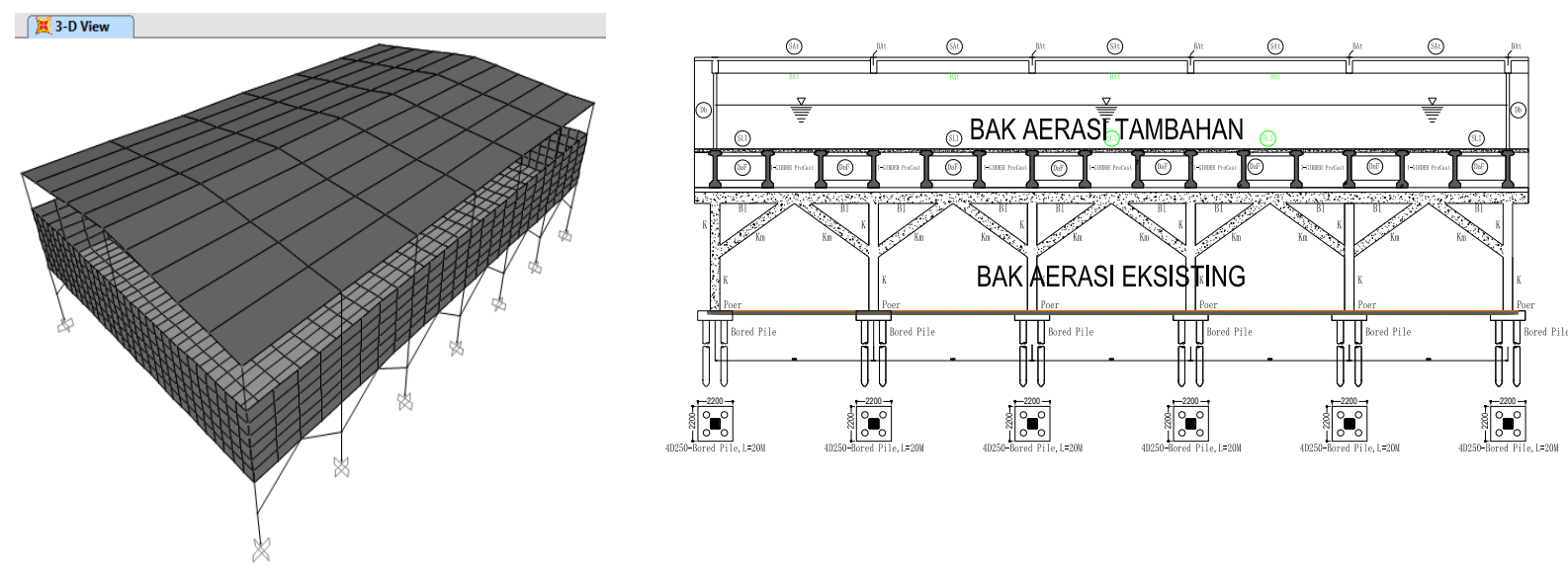

Gambar 10 Denah dan potongan Bak Aerasi 

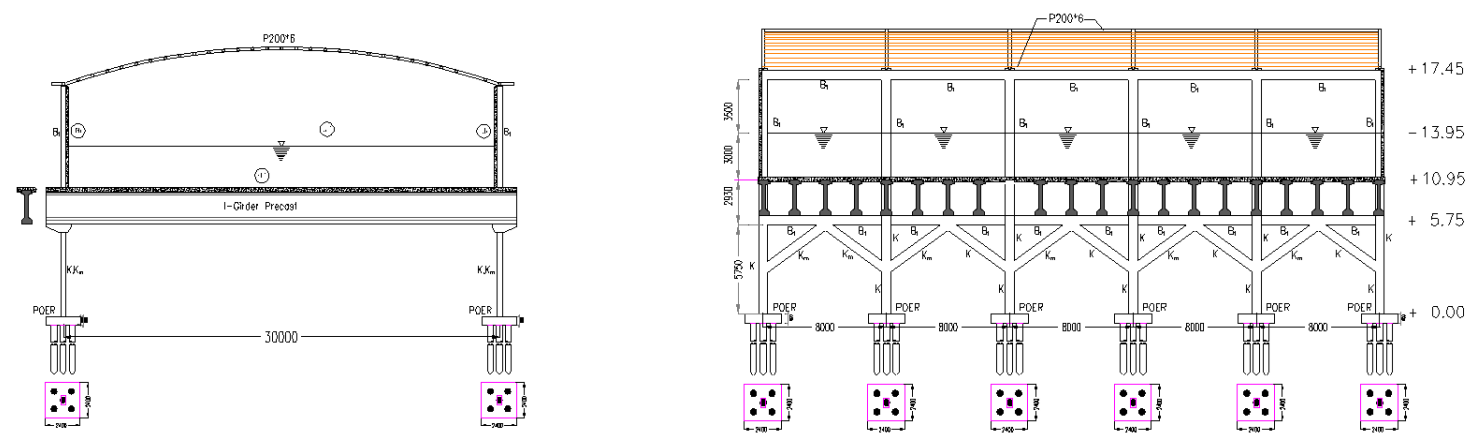

Gambar 11 Pondasi Bak Aerasi 5D400 - 30M di setiap kolom K.

\section{COD H+2 : $: 84,2 \mathrm{mg} / \mathrm{l}$}

Chemical Process - Flocculation (Percobaan

Pertama)

Air Limbah : : Influent IPAL Cisirung

Koagulan : Cair

Merek dagang : Sinerga S512

Dosis $\quad: 0,2 ; 0,4 ; 0,6 ; 0,8 \mathrm{~mL} / \mathrm{L}$

Hasil pertama uji penelitian laboratorium menggunakan proses fisik-kimiawi/ Treatibility Process menggunakan Jar Test menunjukan bahwa kondisi optimum Total Suspended Solid adalah pada waktu ke-15, dengan dosis koagulan $2 \mathrm{~mL} / \mathrm{L}$, nomor Beaker 4 dan kekeruhan sebesar 28,6 NTU.

Chemical Process - Flocculation (Percobaan

Kedua)

Air Limbah $\quad$ : Influent IPAL Cisirung $\rightarrow$ Tanpa Air Banjir

Koagulan : Cair

Merek dagang : Sinerga S512

Dosis $\quad: 0,5 ; 1,0 ; 1,5 ; 2 \mathrm{~mL} / \mathrm{L}$

pH awal : 9,0

pH akhir $\quad: 6,9 \rightarrow$ Beaker no. 4 optimum

Hasil kedua uji penelitian laboratorium menggunakan proses fisik-kimiawi (Jar Test) menunjukkan bahwa kondisi optimum kekeruhan adalah pada waktu ke-15, dengan nomer Beaker 4 dan kekeruhan sebesar 28,6 NTU.

Biological Process - Moving Bed Biological Reactor (MBBR)

Media biofilm carrier : Kaldness (diameter $\mathrm{x}$ lebar = $11 \times 7 \mathrm{~mm}$ )

Surface area
Penempelan mikroba ke media Kaldness

Pemasangan reaktor teknologi MBBR untuk penempelan mikroba ke media filter Kaldness menggunakan metode Batch System.

Setelah pemasangan reaktor, kondisi media Kaldness setelah 2 minggu diperlihatkan pada Gambar 12.

\section{Treatability Trial Pertama: Batch Process}

\begin{tabular}{|c|c|c|}
\hline Volume r & xtor & : 4 Liter \\
\hline Volume $n$ & & : 1 Liter \\
\hline MLSS & $\mathrm{HO}$ & : $2400 \mathrm{mg} / \mathrm{l}$ (suspensi) \\
\hline COD HO & $: 56$ & $\pm 12 \mathrm{mg} / \mathrm{l}$ \\
\hline $\mathrm{COD} \mathrm{H}+1$ & $: 17$ & $22 \mathrm{mg} / \mathrm{l}$ \\
\hline $\mathrm{COD} \mathrm{H}+2$ & $: 84$ & $16 \mathrm{mg} / \mathrm{l}$ \\
\hline COD Rem & & $: 85 \%$ \\
\hline
\end{tabular}

Dalam proses ini, dapat digambarkan suatu kurva penurunan kadar COD seperti pada Gambar 13.

\section{Treatability Trial Kedua: Continuous Process}

$\begin{array}{ll}\text { Volume reaktor } & : 4 \text { Liter } \\ \text { Volume media } & : 1 \text { liter } \\ \text { Flowrate } & : 800 \mathrm{ml} / \mathrm{jam} \\ \text { Td } & : 5 \mathrm{jam}\end{array}$

Hasil percobaan kedua dalam Continuous Process dirangkum dalam Tabel 1 dan profil penurunannya digambarkan dalam Gambar 14 .

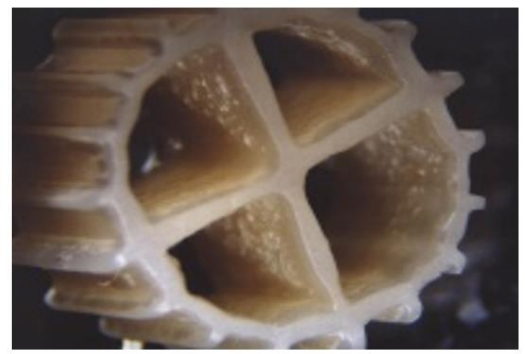

Gambar 12 Media Kaldness Biofilm setelah uji coba 


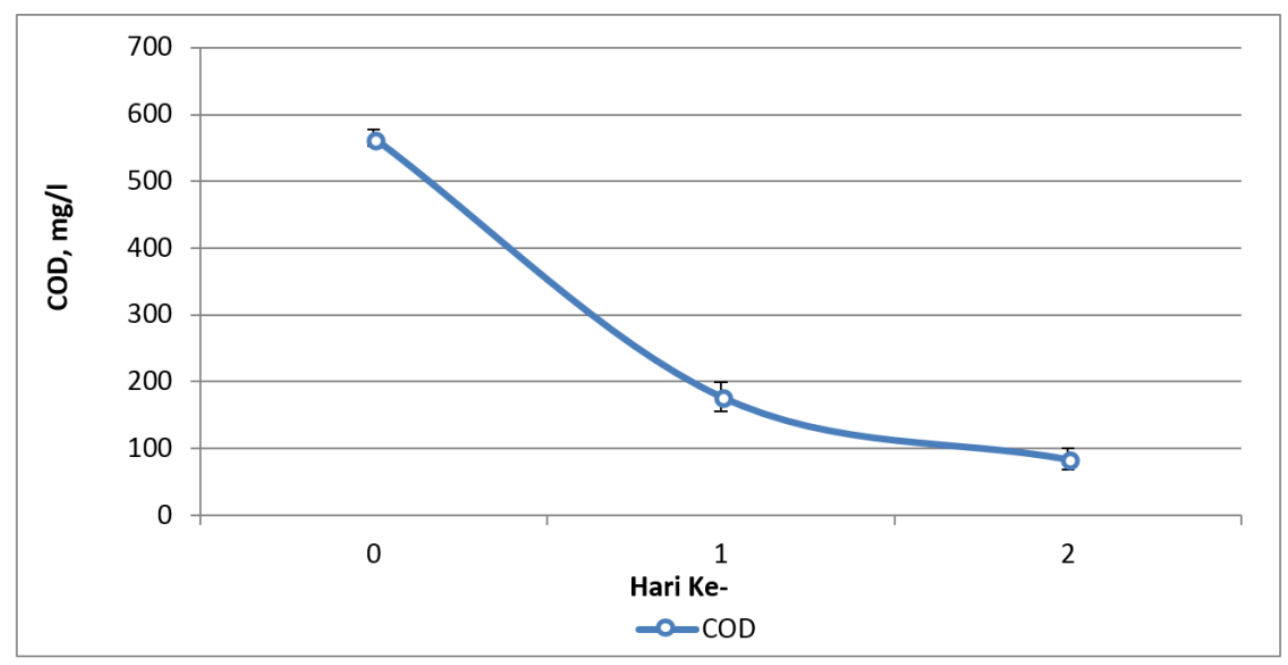

Gambar 13 Profil penurunan kadar COD, percobaan secara batch

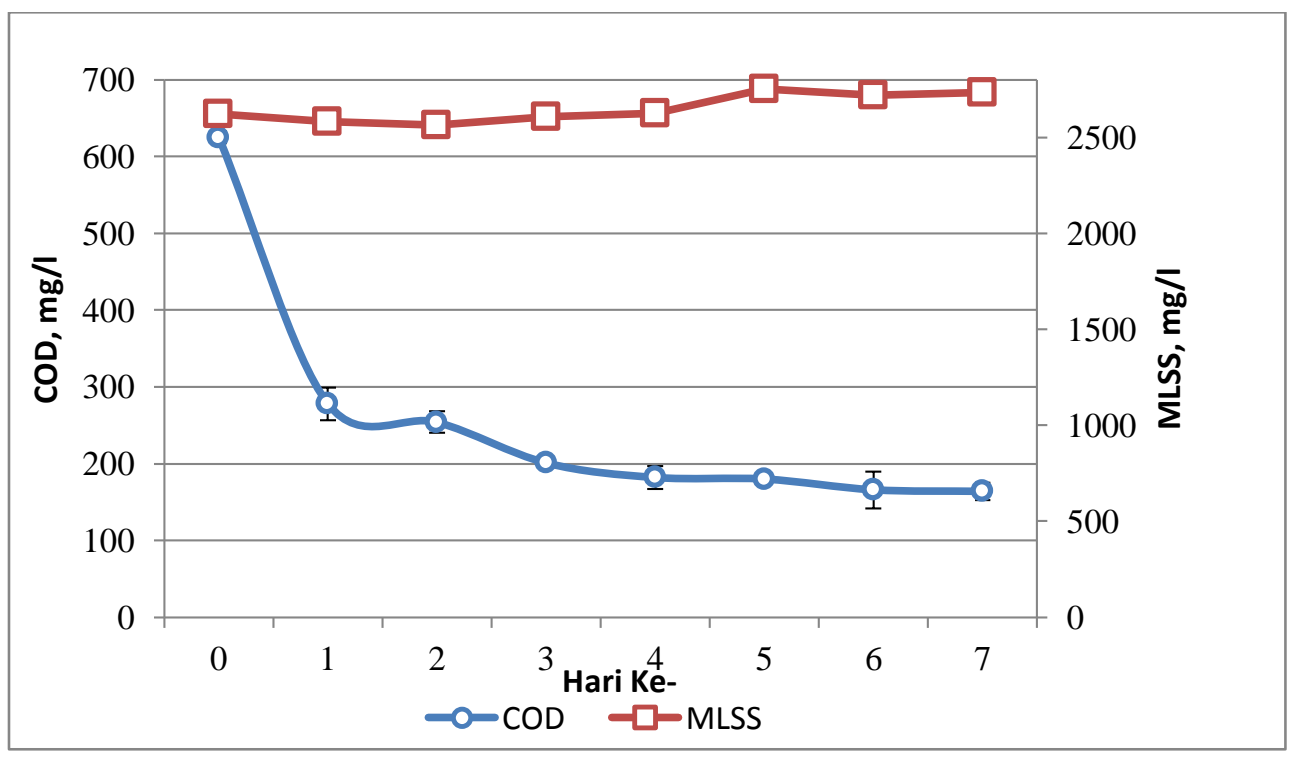

Gambar 14 Profil penurunan kadar COD, percobaan secara kontinyu

Rancang bangun dan spesifikasi teknis IPAL kapasitas 350 L/detik. Dalam desain unit pengolahan limbah tekstil kapasitas individual ini ada beberapa kriteria desain yang ditetapkan, dengan mempertimbangkan kondisi air baku (campuran dengan domestic waste) dan kualitas air keluaran yang ditetapkan adalah sebagai berikut (Tim Cisirung BLLK, 2016).

Kapasitas Pengolahan : $350 \mathrm{~L} /$ detik

Inffluent BOD $\quad: 500 \mathrm{mg} / \mathrm{l}$

Inffluent COD $\quad: 1000 \mathrm{mg} / \mathrm{l}$

Inffluent Nitrogen $(\mathrm{N}) \quad: 50 \mathrm{mg} / \mathrm{l}$

Effluent BOD $\quad: 20 \mathrm{mg} / \mathrm{l}$

Effluent COD $\quad: 40 \mathrm{mg} / \mathrm{l}$

Effluent Nitrogen $\quad: 5 \mathrm{mg} / \mathrm{l}$

\section{Bak Ekualisasi}

Kapasitas Pengolahan

Debit Air Limbah $=350 \mathrm{~L} / \mathrm{s}=30240 \mathrm{~m}^{3} /$ hari $=$ $1260 \mathrm{~m}^{3} / \mathrm{jam}$

Data Perencanaan

Waktu tinggal $(\mathrm{T})=5,5 \mathrm{jam}$ dan $12 \mathrm{jam}$

Dimensi Bak

Volume $\left(\mathrm{V}_{1}\right)=1260 \mathrm{~m}^{3} / \mathrm{jam} \times 5,5 \mathrm{jam}=6930 \mathrm{~m}^{3}$

Volume $\left(\mathrm{V}_{2}\right)=1260 \mathrm{~m}^{3} / \mathrm{jam} \times 12 \mathrm{jam}=15120 \mathrm{~m}^{3}$

Luas Permukaan Existing $(\mathrm{A})=1700 \mathrm{~m}^{2}$ Kedalaman Total $\left(\mathrm{H}_{\mathrm{T} 1}\right)=6930 \mathrm{~m}^{3} / 1700 \mathrm{~m}^{2}=$ $4,08 \mathrm{~m}$

Kedalaman Total $\left(\mathrm{H}_{\mathrm{T} 1}\right)=15120 \mathrm{~m}^{3} / 1700 \mathrm{~m}^{2}=$ $8,89 \mathrm{~m}$ 
Tabel 1 Hasil Percobaan Kualitas Air menggunakan Triatibility Trial Kedua.

\begin{tabular}{c|c|c|c|c}
\hline $\begin{array}{c}\text { Hari } \\
\text { ke- }\end{array}$ & Unit & COD & MLSS & $\begin{array}{c}\text { COD } \\
\text { Removal }\end{array}$ \\
\hline 0 & $\mathrm{mg} / \mathrm{l}$ & $\begin{array}{c}625 \pm \\
8\end{array}$ & 2620 & - \\
\hline 1 & $\mathrm{mg} / \mathrm{l}$ & $\begin{array}{c}278 \pm \\
21\end{array}$ & 2580 & $55 \%$ \\
\hline 2 & $\mathrm{mg} / \mathrm{l}$ & $\begin{array}{c}254.2 \\
\pm 14\end{array}$ & 2564 & $59 \%$ \\
\hline 3 & $\mathrm{mg} / \mathrm{l}$ & $\begin{array}{c}201 \pm \\
4\end{array}$ & 2606 & $68 \%$ \\
\hline 4 & $\mathrm{mg} / \mathrm{l}$ & $\begin{array}{c}182 \pm \\
15\end{array}$ & 2625 & $71 \%$ \\
\hline 5 & $\mathrm{mg} / \mathrm{l}$ & $\begin{array}{c}180 \pm \\
6\end{array}$ & 2750 & $71 \%$ \\
\hline 6 & $\mathrm{mg} / \mathrm{l}$ & $\begin{array}{c}166 \pm \\
24\end{array}$ & 2720 & $73 \%$ \\
\hline 7 & $\mathrm{mg} / \mathrm{l}$ & $\begin{array}{c}164 \pm \\
11\end{array}$ & 2732 & $74 \%$ \\
\hline
\end{tabular}

\section{Unit Kontak Aerasi}

1. Kapasitas Pengolahan

Debit Air Limbah (Q) $=350 \mathrm{~L} / \mathrm{s}=30240$ $\mathrm{m}^{3} /$ hari $=1260 \mathrm{~m}^{3} / \mathrm{jam}$

Debit Resirkulasi $\left(Q_{R}\right)=1260 \mathrm{~m}^{3} \times 50 \%=630$ $\mathrm{m}^{3}$

Debit Total $\left(Q_{\text {total }}\right)=1260 \mathrm{~m}^{3}+630 \mathrm{~m}^{3}=1890$ $\mathrm{m}^{3}$

2. Parameter Desain

Koef Kematian $\left(K_{d}\right)=0,05$ /hari

Koefisien penyisihan BOD terlarut $=5 /$ hari

Koefisien Kinetik Pertumbuhan sel maksimum

= 0,5 $\mathrm{mg} \mathrm{SEL} / \mathrm{mg}$ BOD

Konsentrasi Half Velocity $=30 \mathrm{mg}$ BOD $/ \mathrm{l}$

Umur Lumpur = 10 hari

Rasio Food/Microorganism (F/M) $=0,8125$

Temperatur Udara $=28{ }^{\circ} \mathrm{C}$

Berat udara pada suhu $28{ }^{\circ} \mathrm{C}=1,173 \mathrm{~kg} / \mathrm{m}^{3}$

Konsentrasi Oksigen $=23,2 \%$

Konsentrasi lumpur sirkulasi $\left(\mathrm{X}_{\mathrm{R}}\right)=16500$ $\mathrm{mg} / \mathrm{l}$

MLSS $=5500 \mathrm{mg} / \mathrm{l}$

DO minimum di Bak Aerasi $\left(\mathrm{C}_{\mathrm{L}}\right)=1,5 \mathrm{mg} / \mathrm{l}$

Kelarutan $\mathrm{O}_{2}$ pada suhu standar $20^{\circ} \mathrm{C}\left(\mathrm{C}_{\mathrm{sw}}\right)$ $=9,17 \mathrm{mg} / \mathrm{l}$

Faktor koreksi Tegangan $=0,95$

Faktor koreksi Transfer udara $=1$

Temperatur air limbah $(\mathrm{T})=30$

Faktor Konversi $\mathrm{BOD}_{5}$ menjadi $\mathrm{BOD}_{\mathrm{u}}(\mathrm{f})=0.67$

3. Data Perencanaan

Volume (V)

$$
\text { Volume }=\frac{(10 \times 1890 \times 24 \times 0,50(340-20)}{(5500 \times(1+(10 \times 0.05))}
$$

Setelah dilakukan perhitungan volume yang dibutuhkan untuk Unit Kontak Aerasi yaitu $8797,09 \mathrm{~m}^{3}$.

Waktu Tinggal

$$
\begin{gathered}
\text { Waktu Tinggal }\left(\mathrm{T}_{\mathrm{d}}\right)=\frac{8797,09 \mathrm{~m}^{3}}{1890 \mathrm{~m}^{3} / \mathrm{jam}} \\
=4,65 \mathrm{jam}
\end{gathered}
$$

Waktu tinggal untuk bak kontak aerasi yaitu 4,65 jam sudah sesuai dengan kriteria desain yang ada. Sehingga volume yang dibutuhkan aerasi tidak perlu diubah lagi.

$$
\mathrm{Y}_{\mathrm{obs}}=\frac{0,50}{(1+(0.05 \times 10)}=0,33
$$

Penambahan MLVSS $\left(\mathrm{P}_{\mathrm{x}}\right)$

$$
\mathrm{P}_{\mathrm{x}}=\frac{0,33 \times 1890 \times 24 \times(340-20)}{1000}
$$

dalam hasil perhitungan didapatkan penambahan MLVSS yaitu sebesar $6048 \mathrm{~kg} /$ hari

Penambahan MLSS $\left(\mathrm{P}_{\mathrm{xss}}\right)$

$$
\mathrm{P}_{\mathrm{xSS}}=\frac{6048}{0.8}=7560 \mathrm{~kg} / \mathrm{hari}
$$

dalam hasil perhitungan didapatkan penambahan MLSS yaitu sebesar $7560 \mathrm{~kg} /$ hari

Kebutuhan Oksigen $\left(\mathrm{O}_{2}\right)$

$$
\begin{aligned}
& \left(\left(\frac{1890 \times 24 \times(340-20)}{1000}\right) \times\left(\frac{1}{(0,67-(1,42 \times 0,33))}\right)\right) \\
& +\frac{(1890 \times 24 \times(35-5))}{1000}=13689 \mathrm{KgO}_{2} / \text { hari }
\end{aligned}
$$

dalam hasil perhitungan didapatkan kebutuhan oksigen yang diperlukan yaitu sebesar 13689 $\mathrm{kgO}_{2}$ /hari

Efisiensi Aerator

$$
\frac{13689}{0,8}=17111,36 \frac{\mathrm{KgO}_{2}}{\text { hari }}
$$

dalam hasil perhitungan didapatkan kebutuhan oksigen dengan pertimbangan efisiensi aerator yang diperlukan yaitu sebesar $17111,36 \mathrm{kgO}_{2} /$ hari 
Faktor Keamanan

$2 \times 17111,36=34222,73 \frac{\mathrm{KgO}_{2}}{\text { hari }}=1425,95 \frac{\mathrm{KgO}_{2}}{\text { jam }}$

hasil perhitungan didapatkan kebutuhan oksigen dengan pertimbangan keamanan maka oksigen yang diperlukan yaitu sebesar $34222,73 \mathrm{kgO}_{2} /$ hari atau $1425,95 \mathrm{kgO}_{2} / \mathrm{jam}$.

\section{Upaya Pengendalian Pencemaran Air (PPA) Berkelanjutan}

Yusuf (2016) melakukan penelitian analisis Pengendalian Pencemaran Air (PPA) di zona hulu Sungai Citarum dengan model Multidimensional Scalling. Berdasarkan hasil penelitian tersebut, kompleksitas permasalahan Sungai Citarum menjadi kendala besar untuk melaksanakan berbagai upaya PPA dalam rangka keberlanjutan pengelolaan kualitas air. Hasil analisis menunjukkan adanya indikasi dimensi teknis lebih mudah diimplementasikan dibandingkan dimensi lain seperti sosial-budaya, penegakan hukum, dan yang tersulit adalah dimensi ekonomi. Hal ini dapat dilihat dalam rekapitulasi hasil analisis pada Tabel 2 dan Gambar 15. Hal ini yang menjadi langkah prioritas dalam upaya pengelolaan air limbah di kawasan Cisirung yang masuk ke dalam bagian hulu Sungai Citarum melalui kegiatan revitalisasi yang bersifat teknis. Kegiatan revitalisasi ini diawali dengan desain pokok (basic design) revitalisasi untuk kemudian diimplementasikan untuk menghasilkan kinerja yang optimal untuk IPAL Cisirung.

Dimensi lain yang lebih mudah diimplementasikan adalah dimensi kebijakanhukum. Berkaitan dengan hal tersebut, IPAL Cisirung yang dibangun pada tahun 1984 sampai tahun 1995 telah diserahterimakan pengelolaannya dari Puslitbang Sumber Daya Air kepada Kabupaten Bandung pada tahun 2000. Menurut Berita Acara Serah Terima, pengelolaan IPAL Cisirung ini perlu ditindaklanjuti dengan serah terima aset Barang Milik Negara (BMN) IPAL Cisirung. Namun hingga tahun 2017, serah terima aset ini belum terlaksana antara lain karena tanah tempat berdirinya bangunan IPAL Cisirung bukan merupakan BMN yang dikelola oleh Puslitbang Sumber Daya Air.

Adiana (2017) melakukan analisis pilihan untuk kinerja yang optimum terhadap IPAL Cisirung menggunakan metode Strengths, Weaknesses, Opportunities and Threats (SWOT). Hasil analisis ini memberikan stand-points pilihan optimal bahwa aset yang diserahterimakan adalah aset BMN yang dikelola Puslitbang Sumber Daya Air, yaitu gedung IPAL Cisirung dan peralatan pendukungnya. Tanah tempat berdirinya bangunan IPAL Cisirung yang bukan milik Puslitbang Sumber Daya Air, menjadi urusan Pemerintah Kabupaten Bandung. Pusat Litbang Sumber Daya Air tetap melakukan pemantauan dan evaluasi operasional IPAL Cisirung, penelitian pengembangan, dan memberikan saran (advice) teknis untuk meningkatkan kinerja IPAL Cisirung. Perusahaan Umum Jasa Tirta (PJT) II sebagai institusi nasional yang mempunyai kewenangan memungut, menerima, dan menggunakan biaya jasa pengelolaan sumber daya air, seyogyanya dimanfaatkan sebagai narasumber, pendamping, atau pembina untuk Pihak III/ Swasta yang ditunjuk oleh Pemerintah Kabupaten Bandung sebagai operator IPAL Cisirung.

Rumusan prasyarat untuk mencapai tujuan keberlanjutan pengendalian pencemaran air di Sungai Citarum harus tetap berlandaskan Berita Acara Nomor: 17/BA/M/2000 Tentang Serah Terima Pengelolaan IPAL Cisirung sebagai keputusan yang konsisten mendukung asas desentralisasi/otonomi daerah (Departemen Pemukiman dan Pengembangan Wilayah, 2000). Prasyarat berikutnya adalah Sungai Citarum sebagai sungai strategis nasional berdasar Keputusan Presiden Nomor 12 Tahun 2012 Tentang Penetapan Wilayah Sungai. Prasyarat lainnya adalah peraturan perundang-undangan yang terbaru terkait dengan pengelolaan BMN sebagai acuan dalam serah terima aset IPAL Cisirung.

Tabel 2 Rekapitulasi Hasil Indeks Keberlanjutan Pelaksanaan PPA Citarum.

\begin{tabular}{c|l|c|c|c}
\hline \multirow{2}{*}{ No } & \multicolumn{1}{|c|}{ Dimensi } & \multicolumn{3}{c}{ Indek Keberlanjutan $\left(\boldsymbol{I}_{\boldsymbol{k}}\right)$} \\
\cline { 3 - 4 } & & $\begin{array}{c}\text { Tahun } \\
2015\end{array}$ & $\begin{array}{c}\text { Tahun } \\
2030\end{array}$ & $\begin{array}{c}\text { Tahun } \\
2050\end{array}$ \\
\hline 1. & Kebijakan & $46,52 \%$ & $61,47 \%$ & $69,49 \%$ \\
\hline 2. & Teknis & $46,50 \%$ & $63,92 \%$ & $78,06 \%$ \\
\hline 3. & Ekonomi & $33,18 \%$ & $44,98 \%$ & $53,87 \%$ \\
\hline 4. & Sosial - Budaya & $43,81 \%$ & $51,93 \%$ & $58,13 \%$ \\
\hline 5. & Penegakan Hukum & $42,95 \%$ & $51,12 \%$ & $55,92 \%$ \\
\hline 6. & Dukungan Pemangku kepentingan & $42,97 \%$ & $49,41 \%$ & $53,67 \%$ \\
\hline
\end{tabular}




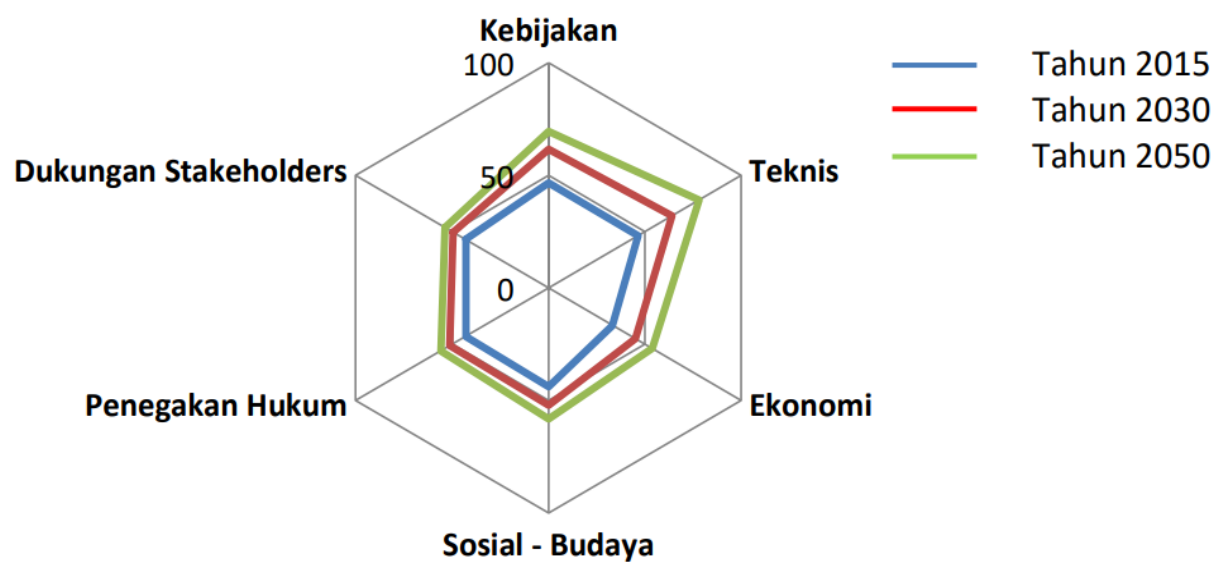

Gambar 15 Indeks keberlanjutan upaya PPA Citarum Tahun 2015, 2030 dan 2050

Sasaran agar pengelolaan IPAL Cisirung bisa optimal adalah bila terjalin keterpaduan antara institusi-institusi yang terlibat atau bisa dilibatkan, yaitu Puslitbang Sumber Daya Air, Balai Besar Wilayah Sungai (BBWS) Citarum, PJT II, Dinas Pengelolaan Sumber Daya Air (PSDA) Provinsi Jawa Barat, Dinas Lingkungan Hidup Provinsi Jawa Barat, Dinas Lingkungan Hidup Kabupaten Bandung, dan Pihak III/ Swasta yang ditunjuk. Semua pihak harus tetap berlandaskan kepada tugas dan fungsi masing-masing, namun bersinergi dalam sistem keberlanjutan pengendalian pencemaran air di Sungai Citarum, terutama dalam pengelolaan IPAL Cisirung.

Analisis menggunakan metode SWOT menunjukkan bahwa institusi yang paling luwes untuk pengoperasian IPAL Cisirung adalah PJT II dan Pihak III/ Swasta, karena dapat memungut, menerima, serta menggunakan biaya jasa pengelolaan IPAL Cisirung. Namun untuk PJT II kemungkinan besar ada penolakan oleh Kabupaten Bandung karena tidak sesuai dengan asas desentralisasi, dan untuk Pihak III/ Swasta harus memiliki daya saing tinggi menghadapi persaingan bebas dalam dunia usaha, apalagi dengan masuknya investor asing. Institusiinstitusi lain yaitu Puslitbang Sumber Daya Air, BBWS Citarum, Dinas PSDA Provinsi Jawa Barat, Dinas Lingkungan Hidup Provinsi Jawa Barat, Dinas Lingkungan Hidup Kabupaten Bandung harus tetap bersinergi sebagai institusi regulator dan kontrol.

\section{KESIMPULAN}

Berkaitan dengan upaya PPA di Sungai Citarum bagian hulu, dimensi teknis lebih mudah diimplementasikan dibandingkan dimensi lain seperti sosial-budaya, penegakan hukum, dan yang tersulit adalah dimensi ekonomi. Upaya PPA ini kemudian diimplementasikan di IPAL Cisirung yang terletak di kawasan industri sepanjang Jalan Mohammad Toha, Bandung.

IPAL Cisirung dibangun dengan teknologi pengolahan air limbah secara fisika, kimia, dan biologi. Basic design revitalisasi dengan meningkatkan kapasitas IPAL Cisirung dilakukan agar kinerja IPAL menjadi lebih optimal. Kegiatan revitalisasi dilakukan dengan melakukan survei lapangan dan pengujian sampel di laboratorium.

Berdasarkan investigasi lapangan, IPAL Cisirung mengalami penurunan kinerja pengoperasian IPAL dan teknologi IPAL sehingga hasil olahan tidak optimal. Untuk titik pengambilan sampel berada pada bak ekualisasi, outlet bak pengendap I, dan bak pengendap II. Kualitas air di ketiga titik pengambilan sampel dikategorikan cukup parah karena sebagian besar parameter kualitas air yang diuji melebihi standar baku mutu air. Hasil pengujian laboratorium menggunakan proses kimiawi (Jar Test) menunjukan bahwa kondisi optimum kekeruhan adalah pada waktu ke-15, dengan nomer Beaker 4 dan dengan nilai kekeruhan sebesar 28,6 NTU.

Berdasarkan hasil uji laboratorium, optimasi kinerja IPAL Cisirung dapat dilakukan melalui kegiatan revitalisasi menggunakan teknologi Moving Bed Biofilm Reactor (MBBR). Teknologi ini sangat efektif dalam mereduksi BOD, nitrifikasi, menghilangkan nitrogen, dan tidak perlu melakukan pengembalian lumpur. Teknologi ini juga memberikan peningkatan perlindungan terhadap toxic shock, dan dalam waktu sementara, secara otomatis menyesuaikan pemuatan fluktuasi sehingga dapat terhindar dari kendala banjir.

Dari aspek manajemen, pengelolaan IPAL Cisirung dapat berjalan dengan optimal bila terjalin keterpaduan antara institusi-institusi yang terlibat atau dapat dilibatkan, yaitu Puslitbang Sumber Daya Air, Balai Besar Wilayah Sungai 
(BBWS) Citarum, PJT II, Dinas Pengelolaan Sumber Daya Air (PSDA) Provinsi Jawa Barat, Dinas Lingkungan Hidup Provinsi Jawa Barat, Dinas Lingkungan Hidup Kabupaten Bandung, dan Pihak III/ Swasta yang ditunjuk.

\section{UCAPAN TERIMA KASIH}

Penulis mengucapkan terima kasih kepada Kepala pusat Litbang SDA atas bimbingan dan masukan-masukannya, kepada rekan-rekan dan semua pihak yang memberikan dukungan dan masukannya, sehingga makalah ini dapat tersusun.

\section{DAFTAR PUSTAKA}

Adiana, R. 2017. Pilihan untuk Kinerja yang Optimum terhadap Barang Milik Negara (BMN) Instalasi Pengolahan Air Limbah (IPAL) Cisirung, Daerah Industri Bandung Selatan. Seminar Litbang, Pusat Penelitian dan Pengembangan Sumber Daya Air.

American Public Health Association. 1999. Standard Methods for the Examination of Water and Wastewater. America Water Works Association, Water Environment Federation.

College of Tropical Agriculture and Human Resources. 2010. Guidelines for Livestock Waste Management. University of HawaiiManoa in collaboration with Hawaii State Department of Health.

Departemen Permukiman dan Pengembangan Wilayah. 2000. Berita Acara Nomor: 17/BA/M/2000 Tentang Serah Terima Pengelolaan Instalasi Pengolahan Air Limbah (IPAL) Cisirung Daerah Industri Bandung Selatan. Ditandatangani oleh Menteri Kimbangwil dan Bupati Bandung pada tanggal 19 April 2000.

Keputusan Presiden. 2012. Penetapan Wilayah Sungai. Kepres Nomor 12 Tahun 2012.

Lariyah, M. S., Mohiyaden, H. A., Hayder, G., Hussein, A., Basri, H., Sabri, A. F., dan Noh, M. N. 2016. Application of Moving Bed Biofilm Reactor (MBBR) and Integrated Fixed Activated Sludge (IFAS) for Biological River Water Purification System: A Short Review. Earth and Environmental Science 32 (2016) 012005.

Mcquarrie, J. dan Boltz, J. 2011. Moving Bed Biofilm Reactor Technology: Process Applications, Desgin and Performance. Water Environment Research 83 (6): 560-575.
PERMENLHRI. 2014. Baku Mutu Air Limbah. Peraturan Menteri Lingkungan Hidup Republik Indonesia No. 5 Tahun 2014.

PERMENLHRI. 2016. Baku Mutu Air Limbah Domestik. Peraturan Menteri Lingkungan Hidup Republik Indonesia No. P.68/MenlhkSetjen/2016.

PT. Darma Indra Bandung. 2008. Pengelola IPAL Cisirung Bandung Selatan.

Puslitbang Sumber Daya Air. 2012. Data Kualitas Air, DAS Citarum. Balai Lingkungan Keairan. Bandung.

Pusltibang Sumber Daya Air. 2016. Basic Design Revitalisasi Cluster IPAL Industri Cisirung, Output Kegiatan Teknologi Restorasi Kualitas Air Sungai Citarum Hulu. No. SM/IP16.01/01.a.6/LK/2016.

Standar Nasional Indonesia. 2008. Air dan Air Limbah - Bagian 59: Metode Pengambilan Contoh Air Limbah. SNI 6989.59.2008.

Standar Nasional Indonesia. 2009. Air dan Air Limbah - Bagian 2: Cara Uji Kebutuhan Oksigen Kimiawi (Chemical Oxygen Demand/COD) dengan Refluksi Tertutup secara Spektrofotometri. SNI 6989.2:2009.

Standar Nasional Indonesia. 2009. Air dan Air Limbah - Bagian 72: Cara Uji Kebutuhan Oksigen Biokimia (Biochemical Oxygen Demand/BOD). SNI 6989.72:2009.

Tchobanoglous, G., Burton, F. L., dan Stensel, H. D. 2003. Wastewater Engineering: Treatment and Reuse, Edisi 4. McGrawHill, USA.

Tim Cisirung BLKK. 2016. Teknologi Restorasi Kualitas Air Sungai Citarum Hulu. Kegiatan Revitalisasi Cluster IPAL Industri Cisirung. Puslitbang Sumber Daya Air.

Undang-undang Republik Indonesia. 2009. Perlindungan dan Pengelolaan Lingkungan Hidup. UU No. 32 Tahun 2009.

Yusuf, I. A. 2016. Analisis Pengendalian Pencemaran Air di Zona Hulu Sungai Citarum dengan Model Multidimensional Scalling. Jurnal Sumber Daya Air, 12 (1), 17 - 32.

Yusuf, I. A., Sudjianto, W., dan Rahmilia, S. 2016. Basic Design Revitalisasi Cluster IPAL Industri Cisirung. Seminar Hasil Litbang, Pusat Litbang Sumber Daya Air. 